\title{
Analisis Sistem Informasi Manajemen Bagi Pendidikan di Masa Pandemi Covid-19
}

\author{
Muhammad Imam FAIZAL \\ Fakultas Ekonomi, STIE STEMBI Bandung Business School, Jalan Buah Batu no.26, Kel. Burangrang, Kec. \\ Lengkong, Kota Bandung, Jawa Barat, Indonesia. \\ imamfaizal0801@gmail.com \\ Vira Nur INTAN * \\ Fakultas Ekonomi, STIE STEMBI Bandung Business School, Jalan Buah Batu no.26, Kel. Burangrang, Kec. \\ Lengkong, Kota Bandung, Jawa Barat, Indonesia. \\ nurintanvira@gmail.com \\ Ricky FIRMANSYAH \\ Universitas Ars \\ JI. Sekolah Internasional No.1-2, Bandung, Provinsi Jawa Barat, Indonesia. \\ ricky@ars.ac.id
}

\section{Article's history:}

Received 16 December 2020; Received in revised form 13 January 2021; Accepted 29 January, 2021; Published 28 February 2021. All rights reserved to the Lembaga Otonom Lembaga Informasi dan Riset Indonesia (KITA INFO dan RISET).

\section{Suggested citation:}

Faizal, M.I., Intan, V.N., Firmansyah, R. 2021. Analisis Sistem Informasi Manajemen Bagi Pendidikan di Masa Pandemi Covid19. JEMSI (Jurnal Ekonomi, Manajemen, dan Akuntansi), Volume 7 (1): 9-16. DOI: https://doi.org/10.35870/jemsi.v7i1.512.

\section{ABSTRAK:}

Sistem Informasi Manajemen pendidikan ditengah pandemi sangatlah penting untuk diimplementasikan. Adanya sistem informasi ini akan mempermudah semua pihak untuk mengerti dan memahami bagaimana informasi pendidikan tersebut dapat terlaksanakan dengan baik. Pendidikan yang ideal dapat diberikan atau diterima oleh semua pihak yang ada di dalamnya, seperti guru, dosen, murid, mahasiswa dan sebagainya, tidak mengenal pendidikan dasar maupun tinggi diharapkan mampu memaksimalkan berbagai kumpulan dan penerapan dari sistem informasi tersebut. Tujuan dari penelitian ini adalah untuk memberikan informasi mengenai Sistem Informasi Manajemen (SIM) bagi pendidikan di masa Corona Virus Disease. Penelitian ini menggunakan metode kuantitatif deskriftif di mana data yang diperoleh didapatkan dari hasil survey online melalui goolge form. Subjek dari penelitian ini ialah sistem informasi manajemen. Hasil dari penelitian menunjukkan bahwa penerapan sistem informasi manajemen telah dilakukan dan dimanfaatkan pada dunia pendidikan. Sistem informasi manajemen sendiri memberikan banyak dampak bagi pendidikan. Dengan diterapkannya sistem informasi manajemen pada pendidikan membawa berbagai pengaruh positif bagi pengguna.

Kata Kunci: Sistem; Pendidikan; Covid-19.

JEL Classification: L86; D83 ; 123.

\section{PENDAHULUAN}

Merebaknya dan menyebarnya virus Corona awal tahun 2020 membuat dunia dibuat berhenti sejenak dari riuh aktifitas hariannya. Virus COVID-19, sebagaimana telah ditetapkan oleh WHO (World Health Organization) dinaikkan statusnya dari epidemi menjadi pandemi. Salah satu jalan keluar yang dapat memberi solusi yaitu tetap mempertahankan proses pembelajaran sebagaimana mestinya dengan cara memperlakukan tatap muka secara DARING, atau secara sadar semua komponen dipaksa untuk melakukan transformasi proses pembelajaran yang berbasis internet. Sesuai SE Kemendikbud Nomor 4 Tahun 2020 tentang Pelaksanaan Pendidikan Dalam Masa Darurat Coronavirus Disease (Covid-19) bahwa semua kegiatan pembelajaran dilaksanakan secara virtual dan kegiatan pembelajaran dilakukan di rumah. Guru akan berusaha sedapat mungkin agar kegiatan pembelajaran yang dilakukan berhasil. Guru berperan sebagai pengorganisasi lingkungan belajar dan sekaligus sebagai 
fasilitator belajar. Barang tentu pembelajaran yang bersifat daring selalu fleksibel dan dinamis bergerak menuju keterbukaan informasi. (Disdikpora, 2021)

Perkembangan teknologi pada zaman era modern ini sangatlah pesat, saat ini teknologi telah memberikan banyak manfaat dalam kemajuan diberbagai aspek. Perkembangan itu bukan hanya dalam hitungan tahun, bulan, atau hari, melainkan jam, bahkan menit atau detik terutama berkaitan dengan teknologi informasi dan komunikasi yang ditunjang dengan teknologi elektronika. (S.Kom, 2020). Dalam organisasi terutama pendidikan selalu membutuhkan keputusan yang cepat dan tepat. Keputusan yang dicetuskan sangat bergantung pada data-data atau informasi berbagai subsistem. (Nafisah, 2018). Teknologi informasi tentunya menerapkan sistem informasi manajemen di dalamnya. Sistem Informasi Manajemen (SIM) adalah seperangkat struktur dan prosedur kerja meliputi pengumpulan, pemrosesan, analisis, presentasi dan penggunaan informasi dalam sebuah organisasi. Sedangkan dimensi dari SIM itu sendiri adalah teknologi, konteks manajemen, kerangka kerja konseptual struktur informasi dan bentuk susunan data yang digunakan. Bahwa sebuah SIM akan mencapai keberhasilan bilamana dalam pengoperasionalnya meliputi lima tahap, yakni; identifikasi kebutuhan, pengumpulan data, prosesing dan analisis data, provisi informasi dan utilisasi informasi. (Rani, 2021).

Pemanfaatan teknologi informasi kian dibutuhkan guna meningkatkan kualitas pembelajaran yang dilaksanakan secara online. Rony Primanto Hari, Kepala Dinas Kominfo DIY mengatakan bahwa pada dasarnya perencanaan pembelajaran jarak jauh telah dibuat sebelum masa pandemi. Rony mengungkap bahwa adanya pandemi justru mengakselerasi pelaksanaan pembelajaran jarak jauh, meskipun masih mengalami banyak kesulitan di awal penerapannya. (Admin, 2021). Direktur Binus Online Learning, Agus Putranto, mengatakan, pesatnya perkembangan teknologi dan informasi mendukung kemudahan belajar online tanpa banyak hambatan. Selain itu, waktu dan biaya pendidikan yang diinvestasikan menjadi lebih fleksibel serta dapat disesuaikan dengan kebutuhan dan kemampuan. (Hidayat, 2021). Berdasarkan pada pendahuluan ini, kami tertarik untuk menganalisis bagaimana cara kerja sistem informasi manajemen di dunia pendidikan. Mengingat saat ini seluruh dunia sedang ditutupi oleh kabut pandemi Covid-19. Adapun tujuan dari penelitian ini ialah memberikan informasi mengenai sistem informasi manajemen bagi pendidikan di masa Corona Virus Disease.

\section{TINJAUAN KEPUSTAKAAN}

\section{Pengertian Analisis}

Menurut asal katanya tersebut, analisis adalah proses memecah topik atau substansi yang kompleks menjadi bagian-bagian yang lebih kecil untuk mendapatkan pemahaman yang lebih baik. Jadi secara umum, pengertian analisis adalah aktivitas yang terdiri dari serangkaian kegiatan seperti; mengurai, membedakan, dan memilah sesuatu untuk dikelompokkan kembali menurut kriteria tertentu dan kemudian dicari kaitannya lalu ditafsirkan maknanya. Pendapat lain menyebutkan analisis adalah usaha dalam mengamati sesuatu secara mendetail dengan cara menguraikan komponen-komponen pembentuknya atau menyusun komponen tersebut untuk dikaji lebih lanjut. (Prawiro, 2020).

\section{Sistem Informasi Manajemen}

Sistem Informasi Manajemen adalah seperangkat prosedur gabungan yang mengumpulkan dan menghasilkan data yang andal, relevan, dan terorganisir dengan baik yang mendukung proses pengambilan keputusan suatu organisasi. Singkatnya, ini adalah sekelompok proses di mana data diperoleh, dianalisa, dan ditampilkan dengan cara yang berguna untuk tujuan pengambilan keputusan. (Priharto, 2019)

Menurut Margianti dan Suryadi pengertian sistem informasi manajemen adalah suatu sistem berdasarkan komputer yang menjadikan sebuah informasi dapat digunakan oleh para manajer untuk kebutuhan yang sama. Informasi yang terdapat pada sistem informasi manajemen biasanya berisi tentang segala bentuk kejadian di dalam perusahaan, yang merupakan kejadian pada masa lalu, saat ini, hingga prediksi. (14 Pengertian Sistem Informasi Manajemen Menurut Ahli, 2017). Menurut O'brien pengertian sistem informasi manajemen adalah sekumpulan komponen yang saling berkaitan dan bekerja sama untuk mencapai kepentingan bersama dengan menerima input serta menghasilkan output dalam transformasi yang teratur. (14 Pengertian Sistem Informasi Manajemen Menurut Ahli, 2017). 


\section{Karakteristik Sistem Informasi Manajemen}

1. Elemen Sistem

Elemen atau komponen sistem adalah bagian bagian atau subsistem dari sebuah sistem yang lebih besar. Elemen sistem mungkin adalah bagian yang paling kecil dari sistem yang ada. Setiap elemen memiliki tugas, fungsi dan tujuan sendiri sendiri. Namun masing-masing elemen sistem informasi manajemen ini akan saling berinteraksi, terhubung dan bekerja sama antara satu dengan yang lain untuk mencapai tujuannya. Apabila terdapat satu elemen tidak bekerja secara maksimal, maka jalannya keseluruhan sistem informasi manajemen akan terganggu dan menghasilkan ouput yang tidak maksimal.

2. Batasan Sistem

Batas sistem atau yang dikenal dengan boundary adalah batasan ruang lingkup yang membatasi sistem informasi manajemen dengan sistem lainnya. Adanya batasan batasan pada sistem informasi manajemen akan membuat sistem informasi yang ada tidak saling tumpang tindih dengan sistem yang lainnya. Setiap sistem akan melakukan tugas dan fungsinya masing masing.

3. Lingkungan Luar

Lingkungan luar merupakan hal hal yang yang berada di luar batas sistem informasi manajemen yang bisa berpengaruh terhadap operasional sistem informasi manajemen. Lingkungan luar sistem bisa berpengaruh positif dan negatif. Lingkungan luar yang merugikan harus bisa dikendalikan dan ditahan sedemikian rupa agar tidak sering mengganggu kegiatan sistem. Dan lingkungan luar yang menguntungkan harus sebisa mungkin bisa dimanfaatkan dengan baik oleh sistem.

4. Penghubung

Penghubung sistem adalah sebuah media yang menjembatani subsistem satu dengan subsistem yang lain. Data keluaran di satu subsistem yang satu akan menjadi data masukan ketika pindah ke subsistem yang lain. Perpindahan ini memerlukan penghubung. Contoh jaringan koneksi. Apabila dalam sebuah sistem tidak ada penghubungnya, maka ketika sebuah komponen subsistem telah selesai melaksanakan tugasnya, kemudian output yang dihasilkan tidak bisa dipindahkan untuk diproses lebih lanjut kepada subsistem yang lainnya karena tidak ada penghubung. Maka sistem secara keseluruhan tidak akan menghasilkan apa-apa.

5. Masukan Sistem

Masukan atau input adalah data yang dimasukkan kedalam sistem untuk diolah oleh sistem. Karakteristik masukan adalah hal yang paling mendasar yang harus dimiliki oleh setiap sistem. Sistem kerja sebuah sistem informasi berawal dari masukan.

6. Keluaran Sistem

Keluaran atau output adalah data masukan yang telah selesai diolah dan menjadi Informasi. Output adalah informasi yang bisa berupa laporan, grafik, formulir atau berupa perbaikan. Output adalah hasil dari sebuah proses pengolahan data pada sistem. Dan masing masing subsitem dalam sebuah sistem akan menghasilkan output. Output dari subsistem lain akan menjadi input bagi subsistem lain dan kemudian diolah kembali menjadi hasil akhir berupa informasi.

7. Pengolah Sistem

Pengolah sistem adalah pemprosesan data yang masuk kedalam sistem dan diolah sedemikian rupa hingga menghasilkan data keluaran (output) yang akan menjadi sebuah informasi yang berguna. Pengolahan bisa berupa pengklasifikasian data, pengurutan, pencarian, penggabungan data. Apabila sebuah sistem tidak bisa mengolah data, maka data mentah yang ada tetap akan menjadi seperti itu. Tidak akan bisa menjadi sebuah informasi yang berharga.

8. Tujuan Sistem

Sistem informasi manajemen tentu memiliki tujuan yang ingin dicapai. Tujuan SIM adalah untuk memberikan informasi yang berguna bagi para pihak yang membutuhkan. Karena pada awalnya, sebuah sistem informasi disusun dan didesain khusus untuk menghasilkan sebuah informasi yang sesuai dengan apa yang diinginkan oleh pengguna. Tujuan sistem didesain sama persis dengan apa yang diinginkan oleh pengguna. Tujuan sistem yang tidak sama dengan apa yang diinginkan oleh pengguna akan menghasilkan informasi yang tidak berharga.

Informasi menjadi tidak relevan dan tidak bisa digunakan oleh penggunanya sebagai bahan pengambilan keputusan. (8 Karakteristik Sistem Informasi Manajemen, 2017). 


\section{Cakupan Sistem Informasi Manajemen Pendidikan}

Ruang Lingkup SIMDIK Back-office :

1. Koneksi dan setting, Identitas sekolah, setting tahun ajaran, setting kurikulum, koneksi database, dan format tanggal.

2. Pengelolaan Kesiswaan, Pengelolaan biodata masing-masing siswa, beasiswa, kasus kedisiplinan, data kesehatan, data periksa, prestasi, perpindahan (mutasi) siswa, sampai pengelolaan data alumni.

3. Pengelolaan Akademik, Laporan nilai hasil ujian secara periodik, data nilai KTSP, data nilai KBK, data absensi, data bimbingan dan penyuluhan, data kasus siswa, rencana pengajaran, pengelolaan mata pelajaran, penjadwalan, dan prestasi akademik.

4. Pengelolaan Guru dan Karyawan, Manajemen biodata guru dan karyawan, data keluarga, riwayat pendidikan, pendidikan tambahan(kursus, training, seminar, workshop dsb).

5. Pengelolaan Keuangan, Manajemen pembayaran biaya pendidikan, administrasi dana BOS (Bantuan Operasional Sekolah) dan penggunaannya, biaya tambahan, seperti : biaya praktikum, biaya ekstra, dll.

6. Pengelolaan Perpustakaan, Pengelolaan buku (judul, kategori \& deskripsi), status keanggotaan dan peminjam, stock inventory, Jurnal keluar masuk buku, laporan-laporan terdiri dari : statistik peminjaman, statistik keluar masuk buku, rekap peminjaman, dan rekap pengembalian.

7. Pelaporan, Pelaporan siswa (induk siwa, kesehatan, periksa kesehatan, biasiswa, kasus, dan bimbingan) per siswa, per kelas dan seluruh siswa, pelaporan guru/pegawai (induk pegawai, bidang pengajaran), rencana pengajaran, nilai, kelulusan, statistik dan laporan ke DEPDIKNAS (data sekolah, siswa dan guru)

8. Bank Soal, Pengolahan data bank soal, penyimpanan soal,pencarian dan pencetakan. (Charlendita, 2020).

\section{METODE PENELITIAN}

\section{Pendekatan Penulisan}

Metode penelitian ini menggunakan metode kuantitatif deskriftif. Suatu riset kuantitatif yang bentuk deskripsinya dengan angka atau numerik (statistik). (Utama, 2021).

\section{Subjek dan Objek Penelitian}

Subjek penelitian ini adalah sistem informasi manajemen yang digunakan pada pendidikan. Sedangkan objek penelitian ini adalah orang-orang yang berkecimpung dalam dunia pendidikan seperti siswa/i, mahasiswali, guru maupun dosen.

\section{Teknik Pengumpulan Data}

Data yang digunakan diperoleh dari hasil survey online yang diisi oleh para responden melalui google form. Selain itu, kami juga melakukan studi pustaka sebagai referensi di mana kami mengutip artikel/jurnal/makalah yang menunjang data-data hasil penelitian mengenai analisis sistem informasi manajemen bagi pendidikan.

\section{HASIL PENELITIAN DAN PEMBAHASAN}

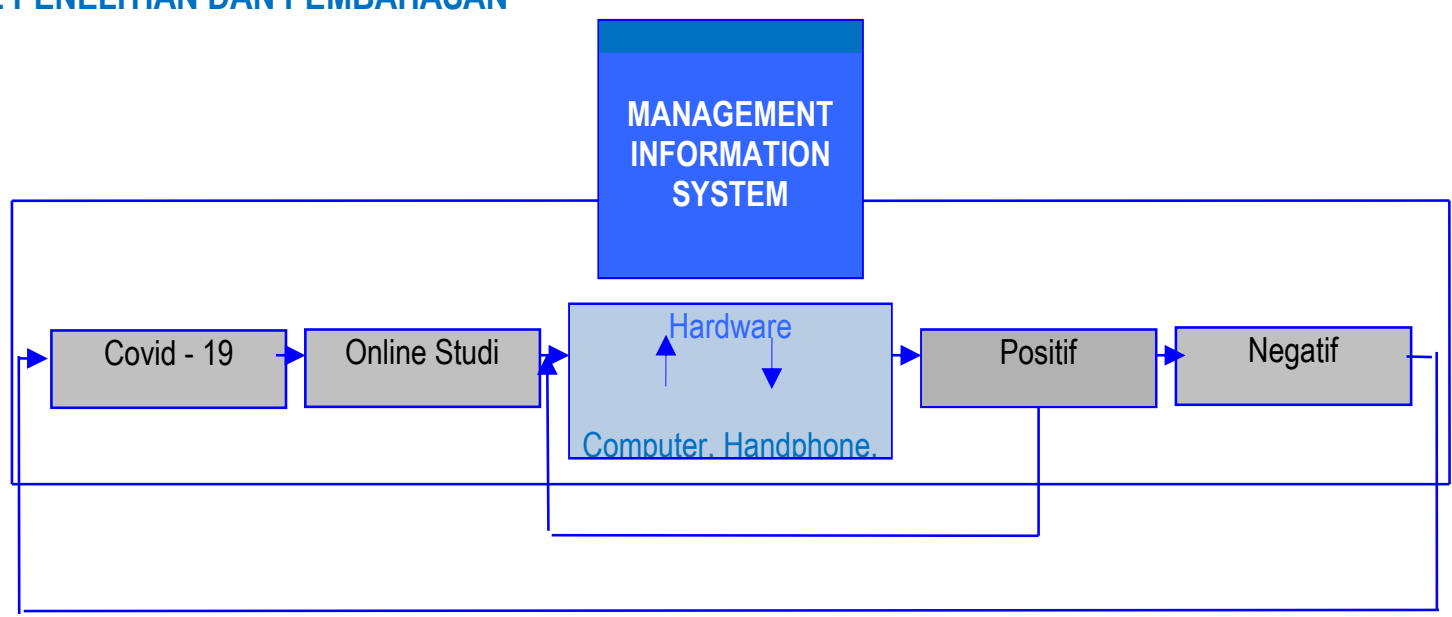

Gambar 1. Hubungan Sistem Informasi Manajemen dengan Pembelajaran Online 
Tabel 1. Usia Responden

\begin{tabular}{|l|l|l|}
\hline Age & Total of Respondent & Percentage \\
\hline $18-20$ years old & 21 persons & $70 \%$ \\
\hline $21-25$ years old & 5 persons & $16.6 \%$ \\
\hline $26->30$ years old & 4 persons & $13.3 \%$ \\
\hline
\end{tabular}

Tabel di atas menunjukkan bahwa $70 \%$ responden berusia rentan 18 - 20 tahun, Hal ini menujukkan bahwa rata-rata yang ikut andil dalam menjawab penelitian ini adalah Siswa/i dan Mahasiswa/i. 16.6\% berusia 21 - 25 tahun, dan sisanya $13.3 \%$ beruisa 26 - lebih dari 30 tahun.

Tabel 2. Keterkaitan Responden dengan Bidang Pendidikan

\begin{tabular}{|l|l|l|}
\hline Connection with Education & Total of Respondent & Percentage \\
\hline Connect & 30 persons & $100 \%$ \\
\hline Unconnect & - & - \\
\hline
\end{tabular}

Seluruh responden adalah orang-orang yang berkecimpung dalam bidang pendidikan. Bisa terlihat dari hasil survey bahwa $100 \%$ narasumber terkait dengan edukasi atau bidang pendidikan.

Tabel 3. Profesi dan Status Responden

\begin{tabular}{|l|l|l|}
\hline Profession/Status & Total of Respondent & Percentage \\
\hline Student & 25 persons & $76.6 \%$ \\
\hline Teacher & 7 person & $23.3 \%$ \\
\hline Lecturer & - & - \\
\hline
\end{tabular}

Siswa/i dan Mahasiswa/i menjadi mayoritas reponden dalam survey online ini. Pada data di atas, $76.6 \%$ responden adalah pelajar. Sedangkan $23.3 \%$ nya adalah seorang guru.

Tabel 4. Penggunakan Sistem Informasi Manajemen

\begin{tabular}{|l|l|l|}
\hline Profession/Status & Total of Respondent & Percentage \\
\hline $\begin{array}{l}\text { Using Management Information } \\
\text { System }\end{array}$ & 28 persons & $93.3 \%$ \\
\hline $\begin{array}{l}\text { Do Not Using Management } \\
\text { Information System }\end{array}$ & - & - \\
\hline $\begin{array}{l}\text { Maybe Using Management } \\
\text { Inormation system }\end{array}$ & 2 person & $6.6 \%$ \\
\hline
\end{tabular}

Mayoritas responden menggunakan sistem informasi manajemen. Dapat dilihat pada tabel di atas bahwa 93.3\% reponden menggunakan sistem informasi manajemen, sedangkan $6.6 \%$ responden mungkin menggunakan sistem informasi manajemen.

Tabel 5. Tingkat Kepentingan Sistem Informasi Manajemen di Masa Pandemi

\begin{tabular}{|l|l|l|}
\hline Level of importance & Total of Respondent & Percentage \\
\hline Very Important & 25 persons & $83.3 \%$ \\
\hline Important & 5 persons & $16.6 \%$ \\
\hline Not Important & - & - \\
\hline
\end{tabular}

Menurut 83.3\% responden, sistem informasi manajemen sangat penting di masa pandemi Covid-19 ini. Sedangkan menurut $16.6 \%$ nya lagi, sistem informasi manajemen ini penting di masa pandemi Covid-19. 
Tabel 6. Tingkat Kepentingan Sistem Informasi Manajemen Bagi Pendidikan

\begin{tabular}{|l|l|l|}
\hline Level of importance & Total of Respondent & Percentage \\
\hline Very Important & 23 persons & $76.6 \%$ \\
\hline Important & 7 persons & $23.3 \%$ \\
\hline Not Important & - & - \\
\hline
\end{tabular}

Menurut $76.6 \%$ responden, sistem informasi manajemen sangat penting bagi pendidikan. Sedangkan menurut $23.3 \%$ nya lagi, sistem informasi manajemen penting bagi pendidikan.

Tabel 7. Penggunaan KBM Online

\begin{tabular}{|l|l|l|}
\hline $\begin{array}{l}\text { Level of importance } \\
\text { Activities }\end{array}$ & Total of Respondent & $86.6 \%$ \\
\hline $\begin{array}{l}\text { Not Doing Online Teaching and } \\
\text { Learning Activities }\end{array}$ & 26 persons & $13,3 \%$ \\
\hline
\end{tabular}

Mayoritas responden atau $86.6 \%$ responden menggunakan platform online untuk melakukan kegiatan belajar mengajar. Sedangkan $16.6 \%$ reponden tidak menggunakan platform online untuk melakukan kegiatan belajar mengajar.

Tabel 8. Keefektifan Pembelajaran Online di Masa Pandemi Covid-19

\begin{tabular}{|l|l|l|}
\hline Effectiveness & Total of Respondent & Percentage \\
\hline Effective & 4 persons & $13.3 \%$ \\
\hline Not Effective & 21 persons & $70 \%$ \\
\hline Maybe Effective & 5 persons & $16.6 \%$ \\
\hline
\end{tabular}

Menurut $70 \%$ responden, pembelajaran online yang dilakukan selama masa pandemi Covid-19 ini tidak efektif. Menurut minoritas 13.3\% responden, pembelajaran online di masa pandemi Covid-19 ini efektif. Sedangkan menurut $16.6 \%$ responden, mungkin efektif.

Tabel 9. Jenis Perangkat Keras yang Digunakan Saat KBM

\begin{tabular}{|l|l|l|}
\hline Hardware & Total of Respondent & Percentage \\
\hline Laptop & 22 persons & $73.3 \%$ \\
\hline Computer & - & - \\
\hline Handphone & 8 persons & $26.6 \%$ \\
\hline
\end{tabular}

Laptop adalah perangkat keras yang digunakan $73.3 \%$ responden untuk media kegiatan belajar mengajar online. Sedangkan $26.6 \%$ responden menggunakan Handphone sebagai media kegaiatan belajar mengajar secara online.

Tabel 10. Hal Positif Selama Pembelajaran Online

\begin{tabular}{|l|l|l|}
\hline Positive Things & Total of Respondent & Percentage \\
\hline More Time With Family & 5 persons & $16.6 \%$ \\
\hline Stay At Home More & 5 persons & $16.6 \%$ \\
\hline Save Commuting Cost & 10 persons & $33.3 \%$ \\
\hline Better Able to Manage Time & 4 persons & $13.3 \%$ \\
\hline Flexible Time & 6 persons & $20 \%$ \\
\hline
\end{tabular}

Lebih banyak waktu bersama keluarga adalah hal positif dari KBM online yang diterima $16.6 \%$ responden. Waktu yang lebih fleksibel adalah hal positif yang diterima oleh $16.6 \%$ responden. Waktu di rumah yang lebih banyak adalah hal positif yang diterima oleh $33.3 \%$ responden. Lebih bisa memanage waktu adalah hal positif yang dirasakan oleh $13.3 \%$ responden. Mayoritas responden atau $20 \%$ responden dapat menghemat ongkos atau biaya pulang pergi. 
Tabel 11. Kendala Selama Pembelajaran Online

\begin{tabular}{|l|l|l|}
\hline Constraint & Total of Respondent & Percentage \\
\hline Bad Internet Network & 20 persons & $66.6 \%$ \\
\hline Wasteful Internet Quota & 5 persons & $16.6 \%$ \\
\hline $\begin{array}{l}\text { Difficulty in Communication with } \\
\text { Lecturers }\end{array}$ & 5 persons & $16.6 \%$ \\
\hline
\end{tabular}

Kendala jaringan internet yang buruk adalah hal negatif yang menghambat pembelajaran online separuh atau $66.6 \%$ responden. Kuota internet yang boros adalah kendala belajar mengajar online $16.6 \%$ responden. Sisanya, $16.6 \%$ responden mengalami kesulitan berkomunikasi dengan dosen. Mohammad Ramdani (18 tahun) adalah seorang mahasiswa di salah satu Universitas. Dalam rentang waktu dua tahun terakhir, ia melakukan kegiatan belajar mengajar secara online dikarena dampak dari pandemi Covid-19. la menggunakan sistem informasi manajemen sebagai penunjang KBM. Menurutnya, sistem informasi manajemen ini sangatlah bermanfaat bagi pendidikan di masa seperti ini. Laptop adalah hardware yang ia gunakan untuk belajar online seperti presentasi serta pengumpulan tugas - tugas. Akan tetapi, menurutnya pembelajaran secara online ini tidaklah efetif, dikarenakan banyak terjadi kendala jaringan dan sebagainya.

Adapun Gustiani Fujia Damayanti (21 tahun) seorang mahasiswi di salah satu universitas. Dari awal tahun 2020 pembelajarannya juga di rumahkan karena Covid-19. la juga menggunakan sistem informasi manajemen sebagai penunjang KBM. Laptop dan Handphone adalah hardware yang digunakannya. Gustiani menyatakan hal postif dari pembelajaran online ini yaitu materi dan penjelasan yang bisa direkam lalu didengarkan ulang. Disamping itu, hal yang membuatnya kesulitan dalam KBM online diantaranya perangkat yang tiba - tiba error, kuota internet boros, jaringan yang tidak stabil, kesulitan dalam menghubungi dosen, serta waktu yang tidak efisien. Guru juga tentunya terseret pada KBM online sama halnya seperti siswa/i dan mahasiswa/i. Seorang guru yang berusia 34 tahun, Neng Neni juga menggunakan sistem informasi manajemen seperti handphone untuk melaksanakan pengajaran online. Beliau menyatakan bahwa sistem informasi manajemen ini sangat penting bagi pendidikan di masa pandemi Covid-19, serta pembelajaran online ini bisa dikatakan efektif karena menurutnya dapat memicu transformasi pendidikan dan juga memicu banyak munculnya aplikasi pembelajaran online. Beliau menggunakan metode video dan vn sebagai media atau penunjang. Di samping itu, tentunya ada beberapa hal yang menjadi batu loncatan. Tidak semua orang mempunyai perangkat untuk melakukan KBM online. Banyak guru dan orang tua siswa yang belum sepenuhnya paham dengan teknologi. Siswa juga menjadi leha - leha dan banyak bermain - main. Akibatnya hal ini menjadikan siswa kurang interaktif.

\section{KESIMPULAN}

Covid-19 menjadikan pendidikan saat ini dilakukan secara virtual atau daring, yang tentu menggunakan sistem informasi manajemen di dalamnya. Pemberlakukan social distancing atau phycal distancing adalah cikal bakal pelaksanaan pembelajaran dari rumah. Dengan pemanfaatan teknologi informasi yang berlaku secara tibatiba, tak jarang membuat pendidik serta peserta didik menjadi kaget, termasuk orang tua yang menjadi pengganti guru di rumah. Adapun hasil daripada penelitian ini diantaranya

1. Sistem Informasi Manajemen sangat berguna bagi dunia pedidikan saat ini. Dengan adanya Sistem Informasi Manajemen memudahkan pembelajaran online di masa pademi covid-19. Secara Sistem Informasi Manajemen merupakan unsur dari teknologi, dan teknologi adalah sarana bagi pendidikan online.

2. Banyak orang merasakan manfaat Sistem Informasi Manajemen bagi pendidikan seperti, waktu yang fleksibel, lebih banyak waktu untuk bersama keluarga, dan menghemat biaya untuk ongkos pulang pergi.

\section{REFERENSI}

[1] 14 Pengertian Sistem Informasi Manajemen Menurut Ahli. (2017, April 14). hal. 1. Dipetik Desember 17, 2021, dari https://www.materidosen.com/2017/04/14-pengertian-sistem-informasi.html

[2] 8 Karakteristik Sistem Informasi Manajemen. (2017, Desember 26). Dipetik Desember 17, 2021, dari http://nichonotes.blogspot.com/2017/12/karakteristik-sistem-informasi-manajemen.html 
[3] A. e.-P. (2021, Juli 31). Pemanfaatan Teknologi Informasi untuk Pembelajaran Online. Dipetik Desember 20, 2021, dari https://www.dprd-diy.go.id/pemanfaatan-teknologi-informasi-untuk-pembelajaran-online/

[4] Charlendita, C. R. (2020, Februari 6). Sistem Informasi Manajemen Pendidikan. Dipetik Desember 17, 2021, dari http://blog.ub.ac.id/chintanaromelia/2020/02/06/sistem-informasi-manajemen-pendidikan/

[5] Disdikpora, A. (2021, Agustus 23). MASA PANDEMI : PEMBELAJARAN DI MASA PANDEMI COVID 19. Dipetik November 17, 2021, dari https://disdikpora.bulelengkab.go.id/informasi/detail/artikel/55-masapandemi-pembelajaran-di-masa-pandemi-covid-19

[6] Hidayat, F. (2021, September 28). Perkembangan Teknologi Informasi Dukung Kemudahan Belajar Online. Dipetik Desember 20, 2021, dari https://www.beritasatu.com/digital/834027/perkembangan-teknologiinformasi-dukung-kemudahan-belajar-online

[7] Nafisah, T. (2018, September 18). SISTEM INFORMASI MANAJEMEN DALAM PENDIDIKAN. hal. 5. Dipetik Desember 20, 2021, dari https://webcache.googleusercontent.com/search?q=cache:g5WEyBLhgVgJ:https://www.slideshare.net/Tik aNafisah/sistem-informasi-manajemen-dalam-pendidikan+\&cd=13\&hl=id\&ct=clnk\&gl=id

[8] Prawiro, M. (2020, Oktober 13). Pengertian Analisis: Memahami Apa Itu Analisis dan Penggunaannya Dalam Istilah. hal. 1. Dipetik November 17, 2021, dari https://www.maxmanroe.com/vid/umum/pengertiananalisis.html

[9] Priharto, S. (2019, Mei 13). Definisi Sistem Informasi Manajemen, Fungsi, Kategori, dan Manfaatnya. hal. 1. Dipetik November 17, 2021, dari https://cpssoft.com/blog/manajemen/definisi-sistem-informasimanajemen-fungsi-kategori-dan-manfaatnyal

[10] Rani. (2021, Januari 5). Peran Teknologi Informasi dalam Sistem Informasi Manajemen. Dipetik Desember 20, 2021, dari https://www.smartcityindo.com/2021/01/peran-teknologi-informasi-dalam-sistem.html

[11] S.Kom, M. F. (2020, November 6). PERAN TEKNOLOGI DAN INFORMASI SERTA APLIKASI ERA PANDEMI COVID 19. hal. 1. Dipetik Desember 20, 2021, dari https://www.smkbpdkw.sch.id/blog/peranteknologi-dan-informasi-serta-aplikasi-era-pandemi-covid-19/

[13] Utama, A. B. (2021, Mei 18). Penelitian Deskriptif: Pengertian, Kriteria, Metode, dan Contoh. Dipetik Desember 20, 2021, dari https://penerbitdeepublish.com/penelitian-deskriptif/ 